\title{
LOSS OF DESICCATION TOLERANCE IN SEEDS OF TREE SPECIES DURING GERMINATION: THEORETICAL AND PRACTICAL IMPLICATIONS ${ }^{1}$
}

\author{
Wilson Vicente Souza Pereira ${ }^{2 *}$, José Marcio Rocha Faria ${ }^{3}$, Olivia Alvina Oliveira Tonetti ${ }^{3}$, Anderson \\ Cleiton José ${ }^{3}$ and Lucas Amaral de Melo ${ }^{3}$

\begin{abstract}
${ }^{1}$ Received on 30.08.2017 accepted for publication on 21.08.2018.
${ }^{2}$ Universidade Federal de Lavras, Graduado em Ciências Biológicas, MG - Brasil. E-mail: <wvicentesp@gmail.com>.

3 Universidade Federal de Lavras, Departamento de Ciências Florestais, Lavras, MG - Brasil. E-mail: <jmfaria@dcf.ufla.br>,<acjose@dcf.ufla.br>,<lucas.amaral@dcf.ufla.br> and<oaotonetti@gmail.com>.

*Corresponding author.
\end{abstract}

\begin{abstract}
Understanding the loss of desiccation tolerance is of great importance in seed technology for its implications in the development of strategies for seed conservation and seedling production. In the present work, the loss of desiccation tolerance was studied in seeds of tree species Bowdichia virgilioides, Libidibia ferrea, Cedrela fissilis, Enterolobium contortisiliquum, Handroanthus impetiginosus, and Piptadenia gonoacantha. The seeds were collected in the region of Lavras, MG, and subjected to desiccation experiments individually for each species. Imbibition curve was created for each species by measuring seed weight at regular intervals under germination conditions. Based on this information, the seeds were allowed to imbibe for a time inferred from the imbibition curve, and then allowed to dry until reaching the initial water content measured before the imbibition begun. Then, the seeds were rehydrated, and those that developed into normal seedlings were considered desiccation-tolerant. The loss of seed desiccation tolerance followed a specific pattern in each studied species, but none of the species was tolerant to desiccation after radicle protrusion. A drastic decrease in desiccation tolerance was observed in P. gonoacantha seeds at the beginning of the germination process. Under the conditions implemented in this study, the loss of desiccation tolerance in all species started at the beginning of the germination process. These results have implications in both theoretical studies (seed priming) and the practice (in seedling production).
\end{abstract}

Keywords: Desiccation sensitivity; Tree species; Germination

\section{PERDA DA TOLERÂNCIA À DESSECAÇÃO EM SEMENTES DE ESPÉCIES FLORESTAIS DURANTE O PROCESSO GERMINATIVO: IMPLICAÇÕES TEÓRICAS E PRÁTICAS.}

\begin{abstract}
RESUMO - A compreensão da tolerância à dessecação é de grande interesse para a tecnologia de sementes, visto que tem aplicação prática no estabelecimento de estratégias para a conservação de sementes e produção de mudas. O presente trabalho objetivou estudar a perda da tolerância à dessecação durante a germinação de sementes das espécies arbóreas sucupira (Bowdichia virgilioides), pau-ferro (Libidibia ferrea), cedro (Cedrela fissilis), tamboril (Enterolobium contortisiliquun), ipê-roxo (Handroanthus impetiginosus) e pau-jacaré (Piptadenia gonoacantha). Sementes coletadas na região de Lavras - MG foram usadas para os experimentos, sendo estes realizados isoladamente para cada espécie. Primeiramente foi estabelecida a curva de embebição por meio da pesagem das sementes nas condições de germinação a intervalos regulares. Baseado nessa informação, as sementes foram postas para embeber por tempos determinados pela curva de embebição e submetidas à secagem até atingir o mesmo percentual de umidade encontrado antes da semeadura. Em seguida as sementes foram reidratadas e aquelas que continuaram a germinação e originaram plântulas normais foram consideradas tolerantes à dessecação. Cada espécie apresentou um padrão próprio quanto à perda da tolerância à dessecação, sendo que em todos os casos, não houve tolerância à dessecação após a protrusão da raiz primária. Contudo, foi observada em sementes de pau-jacaré uma redução mais drástica logo no início
\end{abstract}


do processo germinativo. Nas condições do presente trabalho, observou-se perda da tolerância à dessecação nas primeiras etapas do processo germinativo em todas as espécies, o que pode ter implicações em trabalhos que envolvam o condicionamento fisiológico das sementes.

Palavras-Chave: Sensibilidade à dessecação; Espécies arbóreas; Germinação.

\section{INTRODUCTION}

The ability of an organism to survive critical levels of drying and completely reestablish normal metabolism after water absorption is defined as desiccation tolerance (Oliver et al., 2014). It is present in all types of organisms from microorganism to animal species (Alpert, 2000). In plant species, it is commonly observed in pollen, seeds, and spores (Hoekstra, 2005). Seeds are divided into three classes based on their tolerance to desiccation and storage (Roberts, 1973; Ellis et al., 1990): orthodox (survive the drying during long storage periods at low temperatures, including those below zero), recalcitrant (sensitive to drying and storage), and intermediate (intermediate behavior between the first two categories).

Germplasm conservation is of great interest to human activity related to conservation of either endangered species or interesting cultivars. Owing to the characteristics of orthodox seeds, their germplasm can be preserved without quality loss, whereas the conservation of desiccation-sensitive recalcitrant and intermediate seeds is challenging. Thus, understanding seed desiccation tolerance is of great importance (Kumar et al., 2013; Dekkers et al., 2015). Research of desiccation tolerance in recalcitrant seeds, due to their nature, is difficult. Orthodox seeds assume a recalcitrant-like behavior during the germination process and thus present a useful model for studying desiccation tolerance/sensitivity in seeds (Sun et al., 1999).

Germinating orthodox seeds have been used in studies on the loss of desiccation tolerance to understand the mechanisms linked to desiccation tolerance (Reisdorph and Koster, 1999; Daws et al., 2007; Pereira et al., 2014; Maia et al., 2016). Those studies have been diverse, ranging from physiological and structural characterizations (Reisdorph and Koster, 1999; Guimarães et al., 2011; Pereira et al., 2014) to molecular and ecological analysis (Maia et al., 2011; Costa et al., 2016; Guimarães et al., 2016; Marques et al., 2017). Furthermore, desiccation tolerance reestablishment studies have been carried out to reactivate the mechanisms lost during the germination process (Buitink et al., 2003; Faria et al., 2005; Vieira et al., 2010; Maia et al., 2011; Masetto et al., 2014).
Initially, the characterization of species such as Medicago truncatula, Arabidopsis thaliana, Pisum sativum, and Peltophorum dubium revealed that seed desiccation tolerance is lost at the end of the germination process (Lin et al, 1998; Reisdorph and Koster, 1999; Buitink et al., 2003; Koster et al., 2003; Albuquerque et al., 2009; Guimarães et al., 2016). Those results lead researches to conclude that the loss of desiccation tolerance was, as a rule, lost only after radicle protrusion. Consequently, the studies were primarily focused on germinating seeds. However, in some species that produce orthodox seeds, such as Senna multijuga, Cecropia longipes, Luehea seemannii, and Ochroma pyramidale, drying of the seeds before the conclusion of the germination process resulted in seed death (Daws et al., 2007; Rodrigues-Junior et al., 2014). Drying of the seeds at imbibition phase 1 is lethal in Copaifera langsdorffii (Pereira et al., 2014) and neotropical seed species (Daws et al., 2007).

The advancement of the germination process does not result only in the loss of desiccation tolerance, but also in lowered ability to reestablish this tolerance. This was observed by Maia et al. (2011) in Arabidopsis thaliana, in which the reestablishment of desiccation tolerance was possible around radicle protrusion, and completely lost with radicle growth.

The existence of species such as Copaifera langsdorffii (Pereira et al., 2014), Senna multijuga (Rodrigues-Junior et al., 2014), and neotropical seed species (Daws et al., 2007), in which loss of desiccation tolerance occurs before radicle protrusion, invites for characterization of this process in seeds of other species in order to reveal the mechanisms involved in the loss of desiccation tolerance in orthodox seeds from Brazilian native species. Obtained data may provide a tool for advanced studies about this process and allow researchers to acquire important information pertaining to seeds of native species that can be implemented in nursery management and for understanding the plants' adaptive mechanisms in their natural ecosystems.

The present study aimed to characterize the loss of desiccation tolerance in orthodox seeds of six Brazilian tree species during germination. To that end, we selected

Revista Árvore. 2018;42(5):e420503 
species with orthodox seeds: sucupira (Bowdichia virgilioides), Brazilian ironwood (Libidibia ferrea), cedar (Cedrela fissilis), tamboril (Enterolobium contorrtisiliquunn), purple ipê (Handroanthus impetiginosus), and pau-jacaré (Piptadenia gonoacantha). All the species are used for wood extraction, in landscaping, and have significant ecological value (Lorenzi, 2009).

\section{MATERIALAND METHODS}

\subsection{Seed collection, processing and experimental conditions}

Fruits from the six species were collected from transition areas between the seasonal semideciduous forest and the Brazilian Cerrado in Lavras, Minas Gerais. Seed collection was conducted in 2015 and 2016, and the seeds were processed at the Forest Nursery of the Federal University of Lavras according to the recommendations for each individual species. Processed seeds were transferred to the Forest Tree Seed Lab, Federal University of Lavras, and stored in a cold chamber at $5{ }^{\circ} \mathrm{C}$ and $50 \%$ relative air humidity until use. Experiments were conducted from November 2016 to July 2017.

All experiments were carried individually for each species. All the seeds were germinated in a germination chamber Mangelsdorf at $25^{\circ} \mathrm{C}$ under constant light, in controlled room $\left(20^{\circ} \mathrm{C}\right)$. Paper roll moistened to twice its weight using tap water was used as substrate for all the seeds except for the seeds of sucupira; the latter were placed in Petri dishes $9 \mathrm{~cm}$ in diameter lined with two sheets of paper (moistened to the same proportion). Water content in seeds was measured using a $105^{\circ} \mathrm{C}$ oven for $24 \mathrm{~h}$ as described by Brasil (2009); the measurements were conducted in four replicates, 10 seeds each.

Cedar and pau-jacaré seeds were not submitted to pre-germination treatments. For purple ipê, the seed tegument was removed and the seeds were washed in $1 \%$ sodium hypochlorite for $3 \mathrm{~min}$, followed by rinsing under running water for the same time. Brazilian ironwood and tamboril seeds, which were in physical dormancy, were mechanically scarified with sandpaper (Fowler and Bianchetti, 2000). After scarification, the tamboril seeds were immersed in $0.2 \%(\mathrm{v} / \mathrm{v})$ neutral detergent solution for $5 \mathrm{~min}$ and washed in running water for $3 \mathrm{~min}$. Sucupira seeds were scarified by immersion in concentrated sulfuric acid for $15 \mathrm{~min}$, followed by 1 - minute immersion in tap water three times and final washing in running water for $2 \mathrm{~min}$ (Fowler and Bianchetti, 2000).

\subsection{Imbibition curves and loss of desiccation tolerance characterization}

To generate imbibition curves for each species, 40 seeds of each species were weighed and germinated as described above. Each seed was weighed individually at regular intervals, defined according to the imbibition speed observed during the experiment; the tests were terminated when the maximal germination percentage (radicle protrusion) was reached. These data were used to calculate the weight gain percentage (Equation 1). After generating the imbibition curves, sampling points (imbibition times) to be used in the loss of desiccation tolerance experiments were selected.

Formula used to calculate weight gain percentage. Where $\boldsymbol{W G}(\%)=$ weight gain $(\%) ; \boldsymbol{W}_{\mathbf{c}}=$ current weight (g); and $\boldsymbol{W}_{\mathbf{0}}=$ weight at time $0 . \mathrm{Eq} 1$

$$
W G(\%)=\frac{\left(W_{\mathrm{c}}-W_{\mathrm{o}}\right)}{W_{\mathrm{o}}} \times 100
$$

For the loss of desiccation tolerance tests, the seeds were placed under germination conditions at intervals defined by the imbibition curves for each species. For each imbibition time, seed water content was measured as described above. Seed samples for each germination time were placed in a single layer over metallic nets that were suspended over gerbox type boxes filled with $100 \mathrm{~mL}$ blue silica gel and weighed daily until reaching the weight measured before the beginning of the imbibition (target weight). Target weight was calculated using the water content before and after imbibition and the weight of imbibed seeds according to Equation 2 (Hong and Ellis, 1995).

Formula for seed target weight calculation: $\boldsymbol{P a}=$ Target weight; $\boldsymbol{P i}=$ Initial weight; $\boldsymbol{U} \mathbf{i}=$ Initial water content; $\boldsymbol{U} \mathbf{a}=$ Target water content.Eq2

$$
P a=\frac{(100-U i)}{(100-U a)} x P i
$$

After reaching the target weight, the volume of silica gel in the box was reduced to $1 / 3$ of that used for drying to avoid seed drying and reduction in air relative humidity. The seeds were kept under these conditions for additional 3 days to confirm that seeds 
may tolerate desiccation and can be preserved under such conditions (Pereira et al., 2012, 2014). After this period, the seeds were submitted to pre-humidification: silica gel was replaced with $30 \mathrm{~mL}$ of tap water to establish humid atmosphere, which allowed slow imbibition (from atmospheric water) and prevented any damage due to fast imbibition. The seeds were pre-humidified for $24 \mathrm{~h}$, at $25^{\circ} \mathrm{C}$, and under constant light (Pereira et al., 2012, 2014). After that, the seeds were transferred onto a substrate for germination test (paper roll or Petri dishes lined with paper) and kept in the germination chamber at $25^{\circ} \mathrm{C}$ under constant light for germination evaluation. Desiccation tolerance during the germination process was determined by comparing the percentage of normal seedlings developed from treated seeds and that of the control (dry seeds, not submitted to imbibition/ drying process).

\subsection{Experimental design and data analysis}

The experiments were conducted for each species individually at a completely randomized design, with imbibition times (variable for each species) representing separate treatments and four replicates of 25 (germination tests) or 5 (water content tests) seeds per treatment. Data were analyzed using general linear models (GLM) following binomial family and least significance difference test at $5 \%$ probability to identify significant differences. All the analyses were conducted in $\mathrm{R}$ for Windows (R Core Team, 2018).

\section{RESULTS}

During the imbibition process, all the seeds, except those of tamboril, followed the triphasic pattern of imbibition proposed by Bewley et al. (2013), which consists of tree imbibition phases: the first characterized by fast weight gain (physical process) and no metabolic events (phase 1); the second with little or no weight gain, while seed metabolism becomes more intense in preparation for germination (phase 2); and the last (phase 3 ), which started with radicle protrusion and increase in weight. Considering the theoretical pattern proposed by Bewley et al. (2013) for orthodox seeds undergoing germination process, the analysis of weight gain by seeds confirmed the triphasic pattern of seed germination in seeds of sucupira, cedar, purple ipê, and pau-jacaré, being the pattern for this last species well defined (Figure 1A, C, E, and F).

The transition between phases 2 and 3 was little evident on the imbibition curve of pau-ferro seeds (Figure 1B). The imbibition curve for tamboril seeds revealed a constant weight gain, with no distinction between imbibition phases (Figure 1D). Radicle protrusion was observed already at phase 2 in seeds of pau-ferro(Figure 1B) and purple ipê (Figure 1E), and at the end of phase 1 in pau-jacaré seeds (Figure 1F).

The seed water content reached over $40 \%$ in the first $6 \mathrm{~h}$ of imbibition in sucupira, cedar, purple ipê, and pau-jacaré, $24 \mathrm{~h}$ in pau-ferro, and $48 \mathrm{~h}$ in tamboril. Compared with the other species, tamboril and pauferro seeds had the slowest water absorption. In all the six studied species, water content reached 60 to $70 \%$ of seed weight at time of the final imbibition sampling (Table 1). The time required for seeds to reach the highest radicle protrusion percentage varied from 49 (tamboril) to $133 \mathrm{~h}$ (purple ipê).

The pattern of the loss of seed desiccation tolerance was different for each species. A decrease was already observed at the beginning of the imbibition process in sucupira (Figure 1 A), pau-ferro (Figure 1 B), and pau-jacaré (Figure 1 C). The seeds of cedar (Figure $1 \mathrm{C}$ ), tamboril (Figure 1 D), and purple ipê (Figure 1 E) remained desiccation-tolerant during the imbibition phase 1 purple ipê, and their tolerance decreased at the beginning of phase 2 .

For the six studied species, loss of desiccation tolerance decreased drastically (reduction higher than $30 \%$ ) at some point of the germination process. This decrease was observed at the beginning of phase 2 for cedar (Figure 1 C), tamboril (Figure $1 \mathrm{D}$ ), purple ipê (Figure $1 \mathrm{E}$ ), sucupira (Figure $1 \mathrm{~A}$ ), and pau-ferro (Figure $1 \mathrm{~B}$ ). For sucupira (Figure $1 \mathrm{~A}$ ) and pau-ferro (Figure $1 \mathrm{~B}$ ), desiccation tolerance decreased drastically at two time points, the beginning of the germination process and the beginning of phase 2. For tamboril, desiccation tolerance decreased by $50 \%$ before the beginning of phase 2 , decreasing for less than $10 \%$ with the advance of the phase 2 . Among the six studied species, pau-jacaré had the most uncommon behaviora drastic decrease at the beginning of the germination process, from 65 to $23 \%$ at the beginning of the imbibition, followed by a gradual decrease thereafter.

At the time of highest germination percentage, the seeds of all the six species exhibited no desiccation tolerance. In some species (Brazilian ironwood, cedar, tamboril, and purple ipê), desiccation tolerance remained above $50 \%$ until the onset of radicle protrusion, while

Revista Árvore. 2018;42(5):e420503 

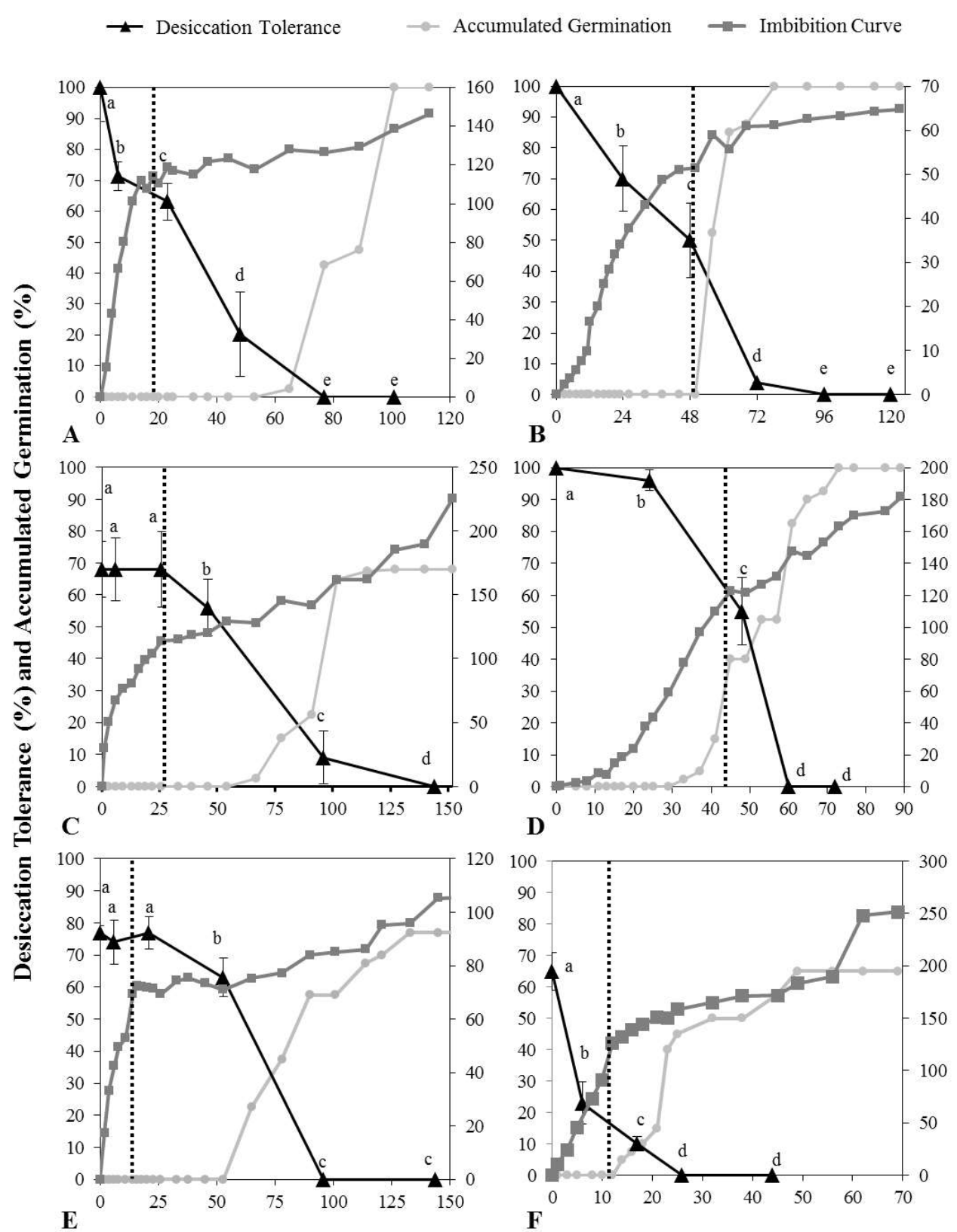

Time (hours)

Figure 1 - Imbibition curve, germination, and loss of desiccation tolerance in seeds of Bowdichia virgilioides (A), Libidibia ferrea

(B), Cedrela fissilis (C), Enterolobium contortisiliquum (D), Handroanthus impetiginosus (E), and Piptadenia gonoacantha (F). Same letters indicates no significant difference between the normal seedlings percentage according to the least significant difference at $5 \%$ probability. Dotted line indicates transition between imbibition phases 1 and 2 .

Figura 1-Curva de embebição, germinação e perda da tolerância à dessecação em sementes de sucupira (Bowdichia virgilioides) (A), pau-ferro (Libidibia ferrea) (B), cedro (Cedrela fissilis) (C), tamboril (Enterolobium contortisiliquun) (D), ipê-roxo (Handroanthus impetiginosus) (E) e pau-jacaré (Piptadenia gonoacantha) (F) durante o processo germinativo. Letras iguais na curva de tolerância à dessecação indicam ausência de diferenças significativas entre os percentuais de plântulas normais em função do tempo embebição, pelo teste de LSD a 5\% de probabilidade. Linha pontilhada indica a transição entre as fases 1 e 2 da embebição. 
Table 1 - Water content (W) in seeds of Bowdichia virgilioides, Libidibia ferrea, Cedrela fissilis, Enterolobium contortisiliquum, Handroanthus impetiginosus, and Piptadenia gonoacantha at different imbibition times (T).

Tabela 1 - Valores de umidade (W) para sementes de Bowdichia virgilioides (sucupira), Libidibia ferrea (pau-ferro), Cedrela fissilis (cedro), Enterolobium contortisiliquun (tamboril), Handroanthus impetiginosus (ipê-roxo) e Piptadenia gonoacantha (pau-jacaré) em diferentes tempos de embebição (T, em horas).

\begin{tabular}{|c|c|c|c|c|c|c|c|c|c|c|c|}
\hline \multicolumn{2}{|c|}{$\begin{array}{l}\text { Bowdichia } \\
\text { virgilioides }\end{array}$} & \multicolumn{2}{|c|}{$\begin{array}{l}\text { Libidibia } \\
\text { ferrea }\end{array}$} & \multicolumn{2}{|c|}{$\begin{array}{l}\text { Cedrela } \\
\text { fissilis }\end{array}$} & \multicolumn{2}{|c|}{$\begin{array}{c}\text { Enterolobium } \\
\text { contortisiliquum }\end{array}$} & \multicolumn{2}{|c|}{$\begin{array}{l}\text { Handroanthus } \\
\text { impetiginosus }\end{array}$} & \multicolumn{2}{|c|}{$\begin{array}{c}\text { Piptadenia } \\
\text { gonoacantha }\end{array}$} \\
\hline$\Gamma(\mathrm{h})$ & W (\%) & T (h) & W (\%) & T (h) & W (\%) & T (h) & W (\%) & T (h) & W (\%) & T (h) & $\mathrm{W}(\%)$ \\
\hline 0 & 8.65 & 0 & 11.31 & 0 & 9.26 & 0 & 10.28 & 0 & 11.19 & 0 & 12.24 \\
\hline 6 & 49.47 & 24 & 46.42 & 6 & 42.64 & 24 & 12.48 & 6 & 41.15 & 6 & 46.86 \\
\hline 23 & 59.50 & 48 & 61.89 & 26 & 56.71 & 48 & 58.86 & 21 & 47.48 & 17 & 66.45 \\
\hline 48 & 60.17 & 72 & 65.58 & 46 & 59.10 & 60 & 64.32 & 53 & 48.76 & 26 & 69.10 \\
\hline 77 & 62.11 & 96 & 69.07 & 96 & 64.04 & 72 & 66.17 & 96 & 54.73 & 44 & 71.30 \\
\hline 101 & 64.96 & 120 & 71.96 & 144 & 69.91 & & & 144 & 63.40 & & \\
\hline
\end{tabular}

that in sucupira and pau-jacaré was less than $50 \%$ before the same germination stage, suggesting premature of the loss of desiccation tolerance for these species.

\section{DISCUSSION}

The triphasic pattern of the imbibition process was clearly observed in all the species, except in tamboril, in which phase 2 was less evident. In seeds that do not enter dormancy (cedar, pruple ipe, and pau-jacaré), the imbibition was fast as the water content in seeds reached $40 \%$ in few hours (Table 1 ). Among the species that produce dormant seeds, similar imbibition pattern to that of non-dormant seeds was observed only in sucupira seeds, which were chemically scarified (15 min with acid immersion) (Table 1), while the seeds of pau-ferro and tamboril required fourto eight-fold longer time to acquire similar water content (Table 1).

In general, the loss of desiccation tolerance in orthodox seeds happens at the end of the germination process, at time of radicle protrusion, as it was observed for Medicago truncatula seeds (Faria et al., 2005). This behavior was also observed in other species with already characterized loss of desiccation tolerance: Sesbania virgata (Masetto et al., 2015), Peltophorum dubium (Guimarães et al., 2011), and Solanum lycopersicum (LIN et al, 1998). Similarly, desiccation tolerance of the seeds of pau-ferro, cedar, tamboril, and purple ipê was maintained at values higher than $60 \%$ until radicle protrusion and then decreased reaching $0 \%$ at the time of highest germination percentage.

A different pattern was observed in seeds of sucupira and pau-jacaré (Figure $1 \mathrm{~A}$ and F). The survival of their seeds was less than $60 \%$ before radicle protrusion, evidencing a precious loss of desiccation tolerance when compared to model species Medicago truncatula and Arabidopsis thaliana (Buitink et al., 2003; Faria et al., 2005; Maia et al., 2011). Similar results were reported for neotropical pioneer species by Daws et al. (2007), who found that seed desiccation tolerance of those species was lost from 63 to $70 \%$ of the time required for the end of germination process. Their study was the first report evidencing the total loss of desiccation tolerance before radicle protrusion. However, the authors only examined the moment at which $100 \%$ of the seeds became sensitive to desiccation, and did not investigate when the loss commenced.

For model species, the decrease in post-desiccation survival usually starts around the end of the germination process, at the time of radicle protrusion-desiccation tolerance remains constant during germination phases 1 and 2, but decreases after visible germination (phase 3) (Buitink et al., 2003; Faria et al., 2005; Maia et al., 2011). That was observed in Medicago truncatula (Buitink et al., 2003; Faria et al., 2005). Similar results were reported for Peltophorum dubium (Guimarães et al., 2011) seeds; the seeds were tolerant to desiccation for up to $50 \mathrm{~h}$ during the imbibition (phase 2), and their tolerance decreased from this point and until the end of germination $(70 \mathrm{~h})$. After germination, regardless of radicle length, the seeds exhibited no tolerance to desiccation. Similar results were observed for Glycine max (Senaratna and Mckersie, 1983). These results suggested that the loss of desiccation tolerance at the end of the germination process (radicle protrusion) was a norm, prompting the researches to test desiccation tolerance only in germinated seeds (Masetto et al., 2014, 2015; Maia et al., 2016). Those studies ignored the possibility that the total loss may occur before

Revista Árvore. 2018;42(5):e420503 
radicle protrusion, as it was observed in the present study for sucupira, pau-jacaré, and pau-ferro seeds, in which the loss of desiccation tolerance commenced already at the beginning of germination.

Seeds of Abelmoschus esculentus and Pisum sativum (Lin et al., 1998; Reisdorph and Koster, 1999) lose their desiccation tolerance before radicle protrusion. The loss commences during the advanced stages of germination, while in sucupira, pau-ferro, and pau-jacaré studied here, the loss of seed desiccation tolerance was initiated in the first hours of imbibition. Similarly, the post-desiccation survival of Copaifera langsdorffii decreases already at imbibition phase 2, with $100 \%$ of seeds becoming desiccation-sensitive at the middle of phase 2 (Pereira et al., 2014, 2017). These data are similar to the ones observed for pau-jacaré (Figure 1F), whose seeds exhibited a drastic decrease in desiccation tolerance in the middle of phase 1 , earlier than in $C$. langsdorffii. The loss of desiccation tolerance at the beginning of the germination was also reported for Senna multijuga seeds (Rodrigues-Junior et al., 2014), thus providing evidence that the loss of seed desiccation tolerance following the model species pattern is not universal.

In phase 1 of the germination process, metabolism is less intense compared with other phases of germination, which explains the maintenance of desiccation tolerance at this stage (Castro et al, 2004; Bewley et al., 2013). Only with the advance of the germination process, as seed metabolism intensifies and reserves are consumed, desiccation tolerance mechanisms are progressively deactivated (Dekkers et al., 2015) until reaching a point where seeds should not be exposed to drying. Thus, loss of desiccation tolerance is not expected to occur before imbibition phase 2. This diverges from the results observed in the present study, as a decrease in seed desiccation tolerance was observed at the beginning of the germination process in sucupira, purple ipê, and, to a greater degree, in pau-ferro and pau-jacaré. This may be due to metabolic events occurring at the beginning of the germination process including the deactivation of desiccation tolerance mechanisms.

Besides the loss of desiccation tolerance, the reestablishment of this tolerance is usually analyzed to understand the mechanisms linked to this process. Typically, germinated seeds are treated with osmotic solutions, salts, and ABA to induce them to reactivate the desiccation tolerance mechanisms during germination (Buitink et al., 2003; Faria et al., 2005; Vieira et al., 2010; Maia et al., 2011). These treatments are usually conducted on germinated seeds, as it is assumed that they lost their desiccation tolerance. However, as evidenced for Arabidopsis thaliana (Maia et al., 2011), there is a short window in the germination process when it is possible to re-induce the desiccation during the germination process. Desiccation tolerance reestablishment studies depend on the correct characterization of the loss, and they aim to identify which stages of the germination process exhibit total sensitivity to desiccation and to select the most suitable stage for re-establishment of desiccation tolerance (Guimarães et al., 2011). The importance of the accurate loss of desiccation tolerance characterization is evident in the present study, especially for pau-jacaré, whose seeds became sensitive to desiccation already at the beginning of the germination process. Thus, in the case of the species studied here, the use of only germinated seeds may lead to false results as the loss of desiccation tolerance may be complete before radicle protrusion.

\section{CONCLUSION}

The loss of desiccation tolerance in cedar, purple ipê, Brazilian ironwood, and tamboril follows a similar pattern to that described in literature for model species such as Arabidopsis thaliana.

The loss of desiccation tolerance is precocious in sucupira and pau-jacaré seeds and more evident in the latter.

\section{ACKNOWLEDGEMENTS}

Authors thank the "Coordenação de Aperfeiçoamento de Pessoal de Nível Superior” (CAPES) for the financial support through scholarship and bench fee for WVSP from the "Programa Nacional de PósDoutorado" (PNPD/CAPES). JMRF received a scholarship from CNPq (Processo PQ 310225/2015-9).

\section{REFERENCES}

Albuquerque KS, Guimarães RM, Almeida IF, Clemente ADCS. Alterações fisiológicas e bioquímicas durante a embebição de sementes de sucupira-preta (Bowdichia virgilioides Kunth.). Revista Brasileira de Sementes. 2009;31(1):12-19. 
AlpertP. The discovery, scope and puzzle of desiccation tolerance in plants. Plant Ecology. 2000;151:5-17.

Bewley J,Bradford K, Hilhorst H, Nonogaki H. Seeds: Physiology of development, germination and dormancy. Springer; 2013.

Brasil. Ministério da Agricultura Pecuária e Abastecimento. Regras para análise de sementes. 2009. [acessado em: 18 de jul. de 2017]. Disponível em: http://www.agricultura.gov.br/ assuntos/insumos-agropecuarios/arquivospublicacoes-insumos/

2946_regras_analise_sementes.pdf.

Buitink J, Vu BL, Satour P, Leprince O. The reestablishment of desiccation tolerance in germinated radicles of Medicago truncatula Gaertn. seeds. Seed Science Research. 2003;13(4):273-86.

Castro RDD, Bradford KJ, Hilhorst HWM. Embebição e reativação do metabolismo. In: Ferreira AG, Borghetti F. Germinação: Do básico ao aplicado. Porto Alegre: Artmed; 2004. p.149-62.

Costa MCD, Faria JMR, José AC, Ligterink W, Hilhorst HWM. Desiccation tolerance and longevity of germinated Sesbania virgata (Cav.) Pers. seeds. Journal of Seed Science. 2016;38(1):50-6.

Daws MI, Bolton S, Burslem DFRP, Garwood NC, Mullins CE. Loss of desiccation tolerance during germination in neo-tropical pioneer seeds: implications for seed mortality and germination characteristics. Seed Science Research. 2007;17(4):273-81.

Dekkers BJW, Costa MCD, Maia J, Bentsink L, Ligterink W, Hilhorst HWM. Acquisition and loss of desiccation tolerance in seeds: from experimental model to biological relevance, Planta. 2015;241(3):563-77.

Ellis RH, Hong T, Roberts E. An intermediate category of seed storage behavior? I. COFFEE. Journal of Experimental Botany.1990;41(230):1167-74.

Faria JMR, Buitink J, van Lammeren AAM, Hilhorst HWM. Changes in DNA and microtubules during loss and re-establishment of desiccation tolerance in germinating Medicago truncatula seeds. Journal of Experimental Botany. 2005;56(418):2119-30.

Fowler J, Bianchetti A. Dormência em sementes florestais. Colombo: Embrapa Florestas; 2000. 27p. (Embrapa Florestas Documentos, 40).

Guimarães CC, Faria JMR, Oliveira JM, Silva EAA. Avaliação da perda da tolerância à dessecação e da quantidade de DNA nuclear em sementes de Peltophorum dubium (Spreng.) Taubert durante e após a germinação. Revista Brasileira de Sementes. 2011;33(2):207-15.

Guimarães CC, Faria JMR, Hilhorst HWM, Ligterink W, Pereira WVS, José AC. Changes in gene expression and solube carbohydrate contents during the imbibition and re-induction of desiccation tolerance in Peltophorum dubium seeds. Seed Science and Technology. 2016; 44 (1):125-137.

Hoekstra FA. Differential longevities in desiccated anhydrobiotic plant systems. Integrative and Comparative Biology. 2005;45(5):725-33.

Hong TD, Ellis RH. A protocol to determine seed storage behavior. Rome: International Plant Genetic Resources Institute; 1996. (IPGRI Technical Bulletin, 1).

Koster KL, Reisdorph N, Ramsay JL. Changing desiccation tolerance of pea embryo protoplasts during germination. Journal of Experimental Botany. 2003;54(387):1607-14.

Kumar D, Singh P, Yusuf MA, Upadhyaya CP, Roy SD, Hohn T, et al. The Xerophyta viscosa aldose reductase (ALDRXV4) confers enhanced drought and salinity tolerance to transgenic tobacco plants by scavenging methylglyoxal and reducing the membrane damage. Molecular Biotechnology. 2013;54(2):292-303.

Lin TP, Yen WL, Chien CT. Disappearance of desiccation tolerance of imbibed crop seeds is not associated with the decline of oligosaccharides. Journal of Experimental Botany.1998;49(324):1203-12.

Lorenzi H. Árvores brasileiras: manual de identificação e cultivo de plantas arbóreas nativas do Brasil. Nova Odessa: Plantarum; 1992.

Revista Árvore. 2018;42(5):e420503 
Maia J, Dekkers BJW, Provart NJ, Ligterink W, Hilhorst HWM. The re-establishment of desiccation tolerance in germinated Arabidopsis thaliana seeds and its associated transcriptome. PLoS one. 2011;6(12):1-11.

Maia J, Guimarães CC, Silva EAA, Faria JMR. What can cell cycle and ultrastructure tell us about desiccation tolerance in Leucaena leucocephala germinating seeds? Biologia Plantarum. 2016;60(2):320-8.

Marques ER, Vaz TAA, Rodrigues-Junior AG, Davide AC, José AC. In situ germination of two tropical recalcitrant seeds and changes in activity of ROSscavenging enzymes. Trees. 2017;31(5):1785-92.

Masetto TE, Faria JM, Fraiz ACR. Re-induction of desiccation tolerance after germination of Cedrela fissilis Vell. seeds. Anais da Academia Brasileira de Ciências. 2014;86(3):1273-85.

Masetto TE, Faria JMR, Fraiz ACR. Loss and reestablishment of desiccation tolerance in the germinated seeds of Sesbania virgata (Cav.) (Pers.). Acta Scientiarum. Agronomy. 2015;37(3):313-20.

Oliver MJ, Tuba Z, Mishler BD, Ecology SP, Nov N, Oliver J, Tuba Z. The evolution of vegetative desiccation tolerance in land plants. Plant Ecology. 2014;151(1):85-100.

Pereira MD, Soares ER, Lopes JC, Borges EEDLE. Condicionamento osmótico de sementes de cubiu. Revista Caatinga. 2012;25(3):12-7.

Pereira WVS, Faria JMR, Tonetti OAO, Silva EAA. Loss of desiccation tolerance in Copaifera langsdorffii Desf. seeds during germination. Brazilian Journal of Biology. 2014;74(2):501-8.

R Core Team. R: A language and environment for statistical computing. R Foundation for Statistical Computing. Vienna: 2018.

Reisdorph N, Koster K. Progressive loss of desiccation tolerance in germinating pea (Pisum sativum) seeds. Physiologia Plantarum.1999;105(2):266-71.

Roberts EH. Predicting the storage life of seeds. Seed Science and Technology. 1973;1:39-52.

Rodrigues-Junior AG, Faria JMR, Vaz TAA, José AC. Loss of desiccation tolerance and storage behavior in germinating seeds of Senna multijuga: implications for seed germination and conservation. New Forests, 2014;46(2):283-91.

Senaratna T, Mckersie BD. Dehydration injury in germinating soybean (Glycine max L. Merr.) seeds. Plant Physiology. 1983;72(3):620-4.

Sun WQ, Marzalina M, Khoo KC. Desiccation sensitivity of recalcitrant seeds and germinated orthodox seeds: can germinated orthodox seeds serve as a model system for studies of recalcitrance? In: Proceedings of IUFRO Seed Symposium Recalcitrant Seeds. Kuala Lumpur: 1999. p.29-42.

Vieira CV, Silva EAA, Alvarenga AA, Castro EM, Toorop PE. Stress-associated factors increase after desiccation of germinated seeds of Tabebuia impetiginosa Mart. Plant Growth Regulation. 2010;62(3):257-63. 